\title{
Risk of stroke after unilateral or bilateral TKA (simultaneous and staged without discharge) in 327,438 matched patients using data from the National Health Insurance Claims for South Korea
}

\author{
Seung-Beom Han \\ Korea University College of Medicine and School of Medicine \\ Jung-Ro Yoon \\ Veterans Health Service Medical Center \\ Ji-Young Cheong \\ Korea University College of Medicine and School of Medicine \\ Young-Soo Shin ( $\sim$ sysoo3180@naver.com ) \\ Veterans Health Service Medical Center https://orcid.org/0000-0003-1030-9979
}

Research article

Keywords: Knee arthroplasty, unilateral, bilateral, Risk factors, Epidemiology

Posted Date: November 23rd, 2020

DOl: https://doi.org/10.21203/rs.3.rs-19817/v4

License: (c) (1) This work is licensed under a Creative Commons Attribution 4.0 International License.

Read Full License 


\section{Abstract}

Background: Limited data is available regarding the incidence rate and risk factors for stroke associated with unilateral total knee arthroplasty (TKA) and bilateral TKA. This study aims to investigate the incidence rate and risk factors of stroke in patients treated with bilateral TKA compared with patients with unilateral TKA.

Methods: In this retrospective nationwide cohort study, we compared patients undergoing unilateral TKA or bilateral TKA using data from the Korean National Health Insurance claims database between January 1, 2009 and August 31, 2017 and included patients older than 40 years of age who underwent primary TKA by the index date as documented primary diagnosis and first additional diagnosis without a history of stroke during the preceding 1 year. We used matched Cox regression models to compare the incidence rate and risk factors of newly acquired stroke among patients treated with unilateral TKA or bilateral TKA after propensity score (PS) matching.

Results: In the present study, 163,719 patients who received unilateral TKA were matched to 163,719 patients with bilateral TKA (simultaneous and staged without discharge) based on PS. The risk of stroke during the study period was lower in patients treated with bilateral TKA than in patients with unilateral TKA (adjusted hazard ratio [HR] 0.79; $P<0.001$ ). Patients who received bilateral TKA were at decreased risk of stroke when the following variables were present: advanced age (70-79 years, HR 0.76; $P<0.001)$, female sex (HR 0.75; $P<0.001)$, rural area (HR 0.77; $P<0.001)$, small- or medium-sized hospital (HR 0.75; $P<0.001)$, health insurance (HR 0.77; $P<0.001)$, history of hypertension drug use (HR 0.75; $P<0.001)$, congestive heart failure (HR 0.70; $P=0.032)$, connective tissue disease (HR 0.71; $P=0.01)$, diabetes (HR $0.77 ; \mathrm{P}<0.001)$, and diabetes with complication (HR 0.76; $\mathrm{P}=0.034)$.

Conclusions: The risk of stroke was lower in patients treated with bilateral TKA (simultaneous and staged without discharge) than in patients with unilateral TKA. Patients treated with bilateral TKA were at decreased risk of stroke when the following variables were present: age (70-79 years), female sex, health insurance, history of hypertension drug use, and comorbidities, such as congestive heart failure, connective tissue disease, and diabetes. More importantly, we do state that those with simultaneous bilateral TKA and staged bilateral TKA without discharge could have been healthier. This is precisely what the guidelines will implement by South Korea for patient selection aim to do and our data show that the risk of stroke is not increased in selected patients undergoing simultaneous bilateral TKA (SiBTKA) and staged bilateral TKA (StBTKA) without discharge.

\section{Background}

Total knee arthroplasty (TKA) is the most efficacious and successful treatment for advanced osteoarthritis $(O A)$ of the knee.[1, 2] However, $23 \%$ of patients scheduled for unilateral TKA show severe symptoms in the contralateral knee and $93 \%$ of patients required a contralateral TKA within 5 years of index surgery.[3] Moreover, unilateral deformity correction for patients with severe deformities creates 
asymmetric lower limb alignment that can significantly affect rehabilitation.[4] Thus, simultaneous bilateral TKA (SiBTKA) and staged bilateral TKA (StBTKA) without discharge have increased in popularity due to shorter overall recovery time and decreased total cost compared with unilateral TKA and StBTKA with discharge.[5] However, SiBTKA and StBTKA without discharge are associated with potential issues such as increased perioperative complications, including pulmonary embolism, deep vein thrombosis, and stroke.[6, 7] Stroke after TKA is a rare but catastrophic complication associated with high rates of morbidity and mortality.[8] Although the risk of stroke after TKA has been investigated in numerous studies, only small sample sizes were used, which can lead to reduced statistical power.[4, 9] In addition, the incidence and risk factors of stroke in patients treated with unilateral TKA compared with subjects with bilateral TKA have been investigated in only a few large-scale studies.

We performed a nationwide, population-based, retrospective cohort study using the National Health Insurance $(\mathrm{NHI})$ claims database, participation in which is compulsory and required by Korean law and covers up to $98 \%$ of the approximately 50 million people in South Korea.[10] Korea's national registries have recently been the source of numerous epidemiological studies, demonstrating high completeness and validity, with an overall predictive value of diagnosis of 83.4\%.[11] We designed the present study to investigate the incidence rate and risk factors of stroke in patients treated with unilateral TKA compared with subjects with bilateral TKA. It was hypothesized that the risk of stroke would be lower in patients treated with bilateral TKA than in patients with unilateral TKA.

\section{Methods}

\section{Study design and data source}

This nationwide, population-based, retrospective cohort study used the Korean $\mathrm{NHI}$ claims database (diagnoses based on International Classification of Disease, 10th Revision [ICD-10] codes and procedure history based on Electronic Data Interchange [EDI] codes), which includes all claims data from the Korean $\mathrm{NHI}$ program and the Korean Medical Aid program from 2009 until 2016; the data are integrated into the Health Insurance Review and Assessment Service (HIRA) database to include all healthcare utilization data for both inpatients and outpatients. These data contained a de-identification code representing patient age, sex, diagnosis, hospital admissions, dates of visits, and procedure history.[10,12] Additionally, prescribed drug information containing the generic name, prescription date, and duration of prescription was included. The Institutional Review Board (IRB) of our institution approved the study. Consent was specifically waived by the IRB because all personal identifying information was removed from the database.

\section{Selection of study sample and definitions}

The outcomes of interest were incidence rate and risk factors of new-onset postoperative stroke in patients treated with unilateral TKA compared with subjects with bilateral TKA. The study population comprised individuals older than 40 years of age who received TKA (EDI: N2072, N2077) without history of stroke (ICD-10: 160, 161, 162, 163) during the preceding 1 year, as documented by primary diagnosis and 
first additional diagnosis in the NHI database between January 1, 2009 and December 31, 2016. Patients treated with bilateral TKA were classified into two groups: patients who underwent SiBTKA and had two primary TKA procedure codes entered on the same day and patients who underwent StBTKA and had two primary TKA procedure codes entered without discharge. Similarly, patients treated with unilateral TKA were classified into two groups: patients who underwent only one TKA during the study period and patients who underwent a second TKA more than 6 months after discharge of index TKA. This is because the planned-staged cohort (more than 6 months) does not appear to be directly related to the index TKA for the risk of cardiovascular complication. $[6,13]$ New-onset postoperative stroke was defined as history of stroke from the date of primary admission or re-admission for stroke in the hospital following TKA. All patients who were deemed to have had a stroke within 12 months after TKA were identified. Patients considered eligible for newly acquired stroke included subjects who received computed tomography (CT) and magnetic resonance imaging (MRI) within one week after admission as well as subjects undergoing relevant surgical procedures, such as burr hole, craniectomy, craniotomy, or thrombectomy. To assess the diagnostic accuracy of the stroke cases registered in the NHI program, we reviewed the image sets and medical records of all registered stroke patients who received TKA at a single medical center. Two neurosurgeons independently investigated whether registered and suspected cases met the diagnostic criteria for strokes released by $\mathrm{NHI}$.

\section{Potential confounders}

Patient characteristics, comorbidities, and co-medication were considered as confounders in this study. Characteristics were age, sex, location, hospital size, and insurance type. Comorbidities comprised acquired immune deficiency syndrome (AIDS), congestive heart failure (CHF), chronic kidney disease (CKD), chronic obstructive pulmonary disease (COPD), connective tissue disease, transient ischemic attack (TIA), dementia, hemiplegia, myocardial infarction (MI), peptic ulcer disease (PUD), peripheral vascular disease (PVD), liver disease, severe liver disease, malignancy, diabetes, diabetes with complication, atrial fibrillation (AF), valvular heart disease (VHD), carotid artery disease (CAD), and hypothyroidism based on previous diagnoses within one year before the index date. In addition, the Charlson Comorbidities Index was calculated for all patients [14]; those with no comorbidities received a score of 0 points. Information on the use of drugs was based on a three-month period within one year before the index date because, in South Korea, drugs are generally prescribed for three months and are typically used on a continuous basis. Potent anticoagulants, such as aspirin, vitamin $\mathrm{K}$ antagonist, factor Xa inhibitor, and direct thrombin inhibitor, also were selected as confounders because they have been used for thrombophylaxis following TKA. In addition, hospitals were classified into two groups based on size (large: tertiary hospital or general hospital; small or medium: hospital or clinic). In the Korean health care system, the parent category of hospitals includes subcategories of hospitals, general hospitals, and tertiary hospitals, the requirements for whose qualifications are stated by Korean law. As a subcategory, a hospital signifies a small hospital in Korea (30-100 beds). General hospitals are hospitals equipped with more than 100 beds and several specialty departments as designated by law, and tertiary hospitals are large-sized university hospitals selected by the government. 


\section{Statistical analysis}

The results of the study should be randomly selected to ensure that there is no difference in characteristics. However, case-control study works on a specific group, so there is no random assignment, and selection bias cannot be avoided.

Propensity score (PS)-based analyses were used to simultaneously control for a large number of covariates and to mimic some of the particular characteristics of a randomized controlled trial; these analyses provide a more robust, less biased estimate when the number of outcome events is low relative to the number of confounders.[15] PS matching is a method of matching the most similar PS. In this study, PS was calculated using logistic regression and performed one-to-one nearest neighbor matching based on the estimated PS. We fit a logistic regression model to estimate the probability of treatment with unilateral TKA versus bilateral TKA, adjusted for all covariates including age category, sex, comorbidities, and co-medication. We evaluated the balance of measured confounders before and after weighting using absolute standardized differences and considered balance as an absolute value less than 0.1 , which has been used in the literature as the definition of a negligible difference. $[16,17] \mathrm{We}$ calculated the incidence rate per 1,000,000 person-years by dividing the number of stroke events by the total number of person-years at risk and multiplying the result by $1,000,000$. The $95 \%$ confidence interval (Cl) was calculated assuming a Poisson distribution. Subgroup analysis was conducted based on age category, sex, location, hospital size, insurance type, comorbidities and co-medication. Adjusted hazard ratio (HR) and $95 \% \mathrm{Cl}$ were calculated using multivariate logistic regression modelling after adjusting for age, sex, location, hospital size, co-medication, and comorbidities. In addition, a sensitivity analysis was conducted to assess the influence of residual confounding based on insurance type. All analyses were conducted using SAS Enterprise software version 6.1 (SAS Institute, Cary, NC, USA) and R software version 3.4.1 (R Foundation for Statistical Computing, Vienna, Austria).

\section{Results}

Among the 373,847 patients identified from the Korean NHI claims database who met the inclusion criteria, 210,128 underwent unilateral TKA and 163,719 bilateral TKA. The logistic model by which the PS was estimated showed predictive value $(C$ statistic $=0.843$ ), which is a reasonable level detecting differences between the two groups in the outcome variables. After applying the PS matching, 327,438 patients were included in the comparative analysis of unilateral TKA versus bilateral TKA. The details of the cohort selection process are summarized in Figure 1. The association of incidence of stroke and annual procedure volume after unilateral TKA or bilateral TKA in South Korea during the study period is shown in Figure 2, indicating that the incidence of stroke decreased steadily regardless of the type of surgery. The decrease in SiBTKA over time in Korea was unlikely to affect our results because PS matching allowed us to match each patient within the smaller SiBTKA cohort with the patient in the second TKA more than 6 months after discharge of index TKA or unilateral TKA cohort who had the most similar patient characteristics. These two subjects were then removed from the group, and the process 
continued in the same fashion until each patient in the SiBTKA cohort had been matched with a patient in the second TKA more than 6 months after discharge of index TKA or unilateral TKA cohort.

Table 1 shows the baseline characteristics of patients treated with unilateral TKA compared with subjects with bilateral TKA in the overall and PS-matched cohorts. After PS matching, the two groups were balanced in terms of baseline covariates (Fig. 3). Among patients who received unilateral TKA, 1,411 $(0.86 \%)$ developed stroke; $1,168(82.8 \%)$ cases were ischemic and the remaining $243(17.2 \%)$ were hemorrhagic stroke, whereas 1,120 patients $(0.68 \%)$ who underwent bilateral TKA developed stroke; 905 $(80.8 \%)$ cases were ischemic and the remaining 215 (19.2\%) were hemorrhagic stroke. Of the patients experiencing new-onset stroke, 301 (21.3\%) treated with unilateral TKA and 220 (19.7\%) with bilateral TKA experienced a stroke within two weeks.

Table 2 shows the risk of stroke in subgroups based on surgical type, age, sex, location, hospital size, insurance type, comorbidities, and co-medication. The risk of stroke during the entire study period was lower in patients treated with bilateral TKA than in patients with unilateral TKA (HR $0.79,95 \% \mathrm{Cl}: 0.73$ to 0.85). Furthermore, patients who received bilateral TKA were at a decreased risk of stroke when the following variables were present: advanced age (70-79 years, HR $0.76,95 \% \mathrm{Cl}: 0.69$ to 0.84 ), female sex (HR $0.75,95 \% \mathrm{Cl}: 0.71$ to 0.86 ), rural area (HR $0.77,95 \% \mathrm{Cl}: 0.70$ to 0.86 ), small- or medium-sized hospital (HR $0.75,95 \% \mathrm{Cl}: 0.68$ to 0.83 ), health insurance (HR $0.77,95 \% \mathrm{Cl}: 0.71$ to 0.84 ), history of hypertension drug use (HR 0.75, 95\% Cl: 0.54 to 1.04), CHF (HR 0.70, 95\% Cl: 0.51 to 0.97), connective tissue disease (HR 0.71, 95\% Cl: 0.54 to 0.92 ), diabetes (HR $0.77,95 \% \mathrm{Cl}: 0.67$ to 0.89 ), and diabetes with complication (HR $0.76,95 \% \mathrm{Cl}: 0.59$ to 0.98$)$.

Table 3 shows the association of unilateral TKA with bilateral TKA after adjusting for variables that were significant on univariate analysis, indicating that the risk of stroke was lower in patients treated with bilateral TKA than in patients with unilateral TKA (adjusted HR $0.79,95 \% \mathrm{Cl}: 0.73$ to 0.86 ). The sensitivity analysis also supported this finding after adjusting for the same variables as in multivariate analysis and insurance type.

\section{Discussion}

In this nationwide cohort study, patients treated with bilateral TKA had a significantly lower rate of stroke (adjusted HR 0.79) than patients with unilateral TKA. These findings conflict with results in a previous study that showed no significant difference between unilateral TKA and bilateral TKA with respect to postoperative stroke evaluated in a single institution.[9] Furthermore, subgroup analyses stratified based on the factors that affect outcome showed that patients treated with bilateral TKA had a lower risk of postoperative stroke than patients with unilateral TKA when the following variables were present: age (7079 years), female sex, health insurance, history of hypertension drug use, and comorbidities such as CHF, connective tissue disease, and diabetes.

Sex differences are specific characteristics of postoperative stroke with respect to clinical manifestations and outcomes. In a general surgical population, the manifestations of postoperative stroke were found 
more frequently in female patients than in male patients.[18] In contrast, when investigating different patient-related factors and their association with postoperative stroke, the risk of stroke was not significantly different between female and male patients.[9] Notably, in the present study, the risk of stroke was significantly decreased in both male (HR 0.79) and female (HR 0.75) patients treated with bilateral TKA compared with subjects with unilateral TKA, indicating that Korean female patients treated with unilateral TKA have an increased risk of stroke. The mechanism by which the risk of stroke is increased in female patients remains unclear. Proposed explanations for the association between stroke and female sex include a higher rate of embolism in females than males and decreased sensitivity to anticoagulant agents. $[19,20]$ Another potential explanation is that a substantial number of female patients treated with unilateral TKA who required prophylactic anticoagulant agents might be at greater risk of stroke due to lack of use of prophylactic anticoagulant agents during the postoperative period compared with patients with bilateral TKA even though prophylaxis with universal anticoagulant agents is not generally recommended to patients undergoing TKA in South Korea because the incidence of postoperative stroke is relatively low.[21]

$\mathrm{CHF}$ is a commonly reported cardiac complication after bilateral TKA because of suboptimal cardiopulmonary reserve in patients with preexisting comorbid medical conditions and in elderly patients, resulting in greater need for monitoring cardiopulmonary parameters, subsequently leading to a higher rate of admission to the intensive care unit patients treated with bilateral TKA than patients with unilateral TKA.[22, 23] Conversely, in previous studies with relatively small cohorts, significant differences were not reported in terms of cardiac complications between unilateral TKA and bilateral TKA.[24, 25] The large differences among study findings is likely caused by the small numbers of patients enrolled in individual studies. In the present study, a nationwide population-based cohort analysis of 210,128 patients treated with unilateral TKA and 163,719 patients with bilateral TKA was performed, and CHF was most strongly associated with new-onset stroke in patients treated with unilateral TKA. In the current study, patients who received bilateral TKA were divided into two groups: patients who underwent SiBTKA and had two primary TKA procedure codes entered on the same day and patients who underwent StBTKA and had two primary TKA procedure codes entered without discharge. These situations may better identify healthier patients or medically optimized patients who had received bilateral TKA, and the results adequately represent the real-world incidence and disease association.

Unexpectedly, other factors such as advanced age, connective tissue disease, and diabetes were all high risk factors for developing postoperative stroke in patients treated with unilateral TKA. This could be explained by the fact that patients treated with unilateral TKA may be more likely to experience stress and complications associated with preexisting conditions affecting the heart and kidneys which can lead to an ischemic stroke because part of those subjects come from candidates for SiBTKA through a selective preoperative screening process. This suggests that these patients have less access to be under the care of neurologists and may not receive optimal treatment of preexisting comorbidities.

Patients receiving hypertension drug use (non-cardioselective $\beta$-blockers), not surprisingly, had a higher incidence of postoperative stroke resulting from inhibition of $\beta 2$-mediated cerebral vasodilation.[26] We 
found that hypertension drug use was a high risk factor for developing postoperative stroke in patients treated with unilateral TKA. These results may be attributable to the fact that patients treated with unilateral TKA have more patients receiving non-cardioselective $\beta$-blocker therapy, leading to a higher incidence of postoperative hypotension and bradycardia, subsequently increasing postoperative stroke.

This study had several limitations. First, the NHI claims database may contain incorrect diagnoses. To minimize this issue, patients with new-onset stroke were defined as subjects whose documented admission yielded principal diagnoses of stroke, patients who were administered relevant CT or MRI within one week after admission, or subjects who were undergoing surgical procedures for new-onset stroke. Second, lifestyle factors, such as smoking status, alcohol consumption, and dietary data, were not evaluated although they could affect the development of stroke. Moreover, we were unable to capture patients who died from a stroke. These seem important since some patients die before reaching the hospital. Third, not every patient needs a TKA on the opposite knee. Thus, all other kinds of unilateral patients who may have had bilateral osteoarthritis but were only treated with TKA on one side should be excluded from these analyses because it was too risky or too frail to operate the other side later. But, we could not adjust for potential confounders such as the severity levels of comorbidities because the Korean NHI claims database did not provide it and substantial criteria in deciding, which of the two modalities to recommend. Fourth, we do not have any information regarding postoperative outcomes such as infection, blood transfusion, length-of-rehabilitation, range of motion, and functional outcome. Clinical information available in the Korean $\mathrm{NHI}$ claims database is insufficiently reported and thus have limited effect in this comparative analysis. Additionally, we could not report the perioperative protocols used for the cases because of the inability to account for the effect of individual surgeons, the absence of measures that could characterize the severity of the joint disease, the dose of perioperative medications, the type of DVT prophylaxis, and mobilization therapy although they could affect the development of stroke. Fifth, we have a likely biased sample in that those who are deemed eligible for bilateral TKA after screening are healthier than those who undergo unilateral TKA even though we have attempted to limit such bias with multivariate logistic regression analysis and propensity score matching. Finally, a one-year period may not be sufficient to exclude all pre-existing strokes. However, the possibility of selection bias in both unilateral and bilateral TKA groups was equal. Despite these limitations, to the best of our knowledge, this is the first nationwide epidemiological study in which the incidence and risk factors for stroke in patients treated with unilateral TKA or bilateral TKA were evaluated using matched control patients.

\section{Conclusions}

The risk of stroke was lower in patients treated with bilateral TKA (simultaneous and staged without discharge) than in patients with unilateral TKA. Patients treated with bilateral TKA were at a decreased risk of stroke when the following variables were present: age (70-79 years), female sex, health insurance, history of hypertension drug use, and comorbidities such as CHF, connective tissue disease, and diabetes. More importantly, we do state that those with SiBTKA and StBTKA without discharge could have been healthier. This is precisely what the guidelines will implement by South Korea for patient selection aim to 
do and our data show that the risk of stroke is not increased in selected patients undergoing SiBTKA and StBTKA without discharge.

\section{List Of Abbreviations}

TKA: total knee arthroplasty; PS: propensity score; PSM: propensity score matching; SiBTKA: simultaneous bilateral TKA; StBTKA: staged bilateral TKA; NHI: National Health Insurance

\section{Declarations}

\section{Ethics approval and consent to participate}

The current study includes the name of the ethics committee and the committee's reference number.

\section{Consent for publication}

Consent was specifically waived by the approving IRB because all personal identifying information was removed from the database.

\section{Availability of data and materials}

The datasets used and/or analysed during the current study are available within the manuscript.

\section{Competing interests}

The authors declare that they have no competing interests.

\section{Funding}

No benefits in any form have been received or will be received from a commercial party related directly or indirectly to the subject of this article, nor have any funds been received in support of this study.

\section{Authors' contributions}

YSS was responsible for the study concept and design, and supervised the study. SBH, JRY, and JYC were responsible for analysis and interpretation of data. SBH and JRY wrote the first draft of the manuscript, and YSS critically revised the manuscript. YSS did the statistical analysis. YSS is the study guarantor, had full access to all of the data in the study and takes responsibility for the integrity of the data, and the accuracy of the data analysis, and had the final responsibility to submit for publication.

\section{Acknowledgements}

The authors did not receive any outside funding or grants in support of their research for or preparation of this work. The authors would like to thank Mr. Kwang-Young Jung and Ms. Jae-Ok Park for them help in preparing the manuscript. 


\section{References}

1. Nishitani K, Kuriyama S, Nakamura S, Ito H, Matsuda S. A multivariate analysis on the effect of no closed suction drain on the length of hospital stay in total knee arthroplasty. Knee Surg Relat Res 2019;31(1):25-30.

2. Song SJ, Kang SG, Park HC, Bae DK. Comparison of clinical results and risk of patellar injury between Attune and PFC Sigma knee systems. Knee Surg Relat Res 2018;30(4):334-340.

3. Mont MA, Mitzner DL, Jones LC, Hungerford DS. History of the contralateral knee after primary knee arthroplasty for osteoarthritis. Clin Orthop Relat Res 1995;(321):145-150.

4. Wong E, Nguyen CL, Park S, Parker D. Simultaneous, same-anaesthetic bilateral total knee arthroplasty has low mortality and complication rates. Knee Surg Sports Traumatol Arthrosc 2018;26(11):3395-3402.

5. Qadir I, Shah B, Waqas M, Ahmad U, Javed S, Aziz A. Component alignment in simultaneous bilateral versus unilateral total knee arthroplasty. Knee Surg Relat Res 2019;31(1):31-36.

6. Meehan JP, Danielsen B, Tancredi DJ, Kim S, Jamali AA, White RH. A population-based comparison of the incidence of adverse outcomes after simultaneous-bilateral and staged-bilateral total knee arthroplasty. J Bone Joint Surg Am 2011;93(23):2203-2213.

7. Rooke GA, Reves JG, Rosow C. Anesthesiology and Geriatric MedicineMutual Needs and Opportunities. Anesthesiology: The Journal of the American Society of Anesthesiologists 2002;96(1):2-4.

8. Selim M. Perioperative stroke. N Engl J Med 2007;356(7):706-713.

9. Mortazavi SM, Kakli H, Bican O, Moussouttas M, Parvizi J, Rothman RH. Perioperative stroke after total joint arthroplasty: prevalence, predictors, and outcome. J Bone Joint Surg Am 2010;92(11):2095-2101.

10. Kwon S. Thirty years of national health insurance in South Korea: lessons for achieving universal health care coverage. Health Policy Plan 2009;24(1):63-71.

11. Park BJ, Sung JH, Park KD, Seo SW, Kim SW. Report of the evaluation for validity of discharged diagnoses in Korean Health Insurance database. Seoul: Seoul National University 2003;19-52.

12. Lee S, Hwang JI, Kim Y, Yoon PW, Ahn J, Yoo JJ. Venous thromboembolism following hip and knee replacement arthroplasty in Korea: A nationwide study based on claims registry. J Korean Med Sci 2016;31(1):80-88.

13. Chua HS, Whitehouse SL, Lorimer M, Steiger RD, Biom D, Guo L. Crawford RW, Oxon D. Mortality and implant survival with simultaneous and staged bilateral total knee arthroplasty experience from the Australian orthopaedic association national joint replacement registry. J Arthroplasty 2018;33:31673173.

14. Charlson ME, Pompei P, Ales KL, MacKenzie CR. A new method of classifying prognostic comorbidity in longitudinal studies: development and validation. J Chronic Dis 1987;40(5):373-383. 
15. Cepeda MS, Boston R, Farrar JT, Strom BL. Comparison of logistic regression versus propensity score when the number of events is low and there are multiple confounders. American journal of epidemiology 2003;158(3):280-287.

16. Austin PC. An Introduction to Propensity Score Methods for Reducing the Effects of Confounding in Observational Studies. Multivariate Behav Res 2011;46(3):399-424.

17. Austin PC. Balance diagnostics for comparing the distribution of baseline covariates between treatment groups in propensity-score matched samples. Statistics in medicine 2009;28(25):30833107.

18. Bateman BT SH, Wang S, et al. Perioperative stroke and associated mortality afternoncardiac, nonneurologic surgery. Anesthesiology 2011;114(6):1289-1296.

19. Forster A, Gass A, Kern R, Wolf ME, Ottomeyer C, Zohsel K, et al. Gender differences in acute ischemic stroke: etiology, stroke patterns and response to thrombolysis. Stroke 2009;40(7):2428-2432.

20. Cavallari LH, Helgason CM, Brace LD, Viana MA, Nutescu EA. Sex difference in the antiplatelet effect of aspirin in patients with stroke. Ann Pharmacother 2006;40(5):812-817.

21. Rasouli MR, Tabatabaee RM, Maltenfort MG, Chen AF. Acute stroke after total joint arthroplasty: a population-based trend analysis. J Clin Anesth 2016;34:15-

22. Ritter M, Mamlin LA, Melfi CA, Katz BP, Freund DA, Arthur DS. Outcome implications for the timing of bilateral total knee arthroplasties. Clin Orthop Relat Res 1997;(345):99-105.

23. Bullock DP, Sporer SM, Shirreffs TG, Jr. Comparison of simultaneous bilateral with unilateral total knee arthroplasty in terms of perioperative complications. J Bone Joint Surg Am 2003;85A(10):1981-1986.

24. Sliva CD, Callaghan JJ, Goetz DD, Taylor SG. Staggered bilateral total knee arthroplasty performed four to seven days apart during a single hospitalization. J Bone Joint Surg Am 2005;87(3):508-513.

25. Stubbs G, Pryke SE, Tewari S, Rogers J, Crowe B, Bridgfoot L, et al. Safety and costbenefits of bilateral total knee replacement in an acute hospital. ANZ J Surg 2005;75(9):739-746.

26. El Beheiry MH, Heximer SP, Voigtlaender-Bolz J, et al. Metoprolol impairs resistance artery function in mice. J Appl Physiol 2011;111(4):1125-1133.

\section{Tables}


Table 1. Baseline characteristics of patients with unilateral total knee arthroplasty, compared to those with bilateral total knee arthroplasty, in overall cohort and PS matched cohort.

Characteristic

Overall cohort

Unilateral Bilateral difference

TKA,

$\mathrm{n}=\mathbf{2 1 0}$

128
TKA,

$n=163$

719
Standardised PS

Unilateral Bilateral difference

TKA,

$n=163$

719
Standardised

TKA,

$n=163$

719

\section{Demographics}

Stroke type, $\mathrm{n}(\%)$

0.029

0.021

ischemic

1641

(83.5)

905

(80.8)

1168

905

(82.8)

(80.8)

hemorrhagic

324

(16.5)

215

(19.2)

243

(17.2)

215

(19.2)

Time since TKA, $\mathrm{n}$

(\%)

$<2$ weeks

402

(20.5)

220

(19.7)

0.028

0.220

2-6 weeks

130 (6.6) $84(7.5)$

6-12 weeks

185 (9.4)

120

(10.7)

$\begin{array}{lll}301 & 220 \\ (21.3) & (19.7) \\ 94(6.7) & 84(7.5) \\ 126(8.9) & \begin{array}{l}120 \\ (10.7)\end{array} \\ & 231 \\ 313 & (20.6) \\ (22.2) & 465 \\ 577 & 40.9) & (41.5) \\ \end{array}$

3-6 months

451

(22.9)

231

(20.6)

6-12 months

797

(40.6)

465

(41.5)

$17.9 \pm$

$\mathrm{SiB}$

stay \pm SD, d (\%)

$8.5(100)$

$18.1 \pm$

9.3

(23.7)/

StB

$28.3 \pm$

9.9

(76.3)

Mean age \pm SD, y $\quad 69.8 \pm 7.3 \quad 69.8$ $\pm 6.6$
$17.7 \pm$

$8.3(100)$

$\mathrm{SiB}$

$18.1 \pm$

9.3

(23.7)/

StB

$28.3 \pm$

9.9

(76.3)

Age distribution, $\mathrm{n}$

(\%)

0.123

0.001

$69.8 \pm$

6.8

69.8

$\pm 6.6$

0.746

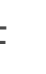

$(0.746$

\begin{tabular}{lllll}
$40-49$ & $\begin{array}{l}1217 \\
(0.6)\end{array}$ & $\begin{array}{l}415 \\
(0.3)\end{array}$ & $400(0.2)$ & $\begin{array}{l}415 \\
(0.3)\end{array}$ \\
\hline $50-59$ & $\begin{array}{l}17566 \\
(8.4)\end{array}$ & $\begin{array}{l}10842 \\
(6.6)\end{array}$ & $\begin{array}{l}11380 \\
(7.0)\end{array}$ & $\begin{array}{l}10842 \\
(6.6)\end{array}$ \\
\hline
\end{tabular}




\begin{tabular}{|c|c|c|c|c|c|c|}
\hline $60-69$ & $\begin{array}{l}77086 \\
(36.7)\end{array}$ & $\begin{array}{l}64163 \\
(39.2)\end{array}$ & & $\begin{array}{l}63617 \\
(38.9)\end{array}$ & $\begin{array}{l}64163 \\
(39.2)\end{array}$ & \\
\hline $70-79$ & $\begin{array}{l}98182 \\
(46.7)\end{array}$ & $\begin{array}{l}79094 \\
(48.3)\end{array}$ & & $\begin{array}{l}78980 \\
(48.2)\end{array}$ & $\begin{array}{l}79094 \\
(48.3)\end{array}$ & \\
\hline$\geq 80$ & $\begin{array}{l}16077 \\
(7.7)\end{array}$ & $\begin{array}{l}9205 \\
(5.62)\end{array}$ & & $\begin{array}{l}9342 \\
(2.7)\end{array}$ & $\begin{array}{l}9205 \\
(5.6)\end{array}$ & \\
\hline Sex, n (\%) & & & 0.291 & & & 0.004 \\
\hline Male & $\begin{array}{l}36710 \\
(17.5)\end{array}$ & $\begin{array}{l}12925 \\
(7.9)\end{array}$ & & $\begin{array}{l}13092 \\
(8.0)\end{array}$ & $\begin{array}{l}12925 \\
(7.9)\end{array}$ & \\
\hline Female & $\begin{array}{l}173418 \\
(82.5)\end{array}$ & $\begin{array}{l}150794 \\
(92.1)\end{array}$ & & $\begin{array}{l}150627 \\
(92.0)\end{array}$ & $\begin{array}{l}150794 \\
(92.1)\end{array}$ & \\
\hline Location, n (\%) & & & 0.182 & & & 0.085 \\
\hline Urban & $\begin{array}{l}82445 \\
(39.2)\end{array}$ & $\begin{array}{l}78931 \\
(48.2)\end{array}$ & & $\begin{array}{l}71981 \\
(44.0)\end{array}$ & $\begin{array}{l}78931 \\
(48.2)\end{array}$ & \\
\hline Rural & $\begin{array}{l}127683 \\
(60.8)\end{array}$ & $\begin{array}{l}84788 \\
(51.8)\end{array}$ & & $\begin{array}{l}91738 \\
(56.0)\end{array}$ & $\begin{array}{l}84788 \\
(51.8)\end{array}$ & \\
\hline Hospital size, $\mathrm{n}(\%)$ & & & 0.056 & & & 0.012 \\
\hline Large & $\begin{array}{l}81706 \\
(38.9)\end{array}$ & $\begin{array}{l}59232 \\
(36.2)\end{array}$ & & $\begin{array}{l}60198 \\
(36.8)\end{array}$ & $\begin{array}{l}59232 \\
(36.2)\end{array}$ & \\
\hline Small or medium & $\begin{array}{l}128422 \\
(61.1)\end{array}$ & $\begin{array}{l}104487 \\
(63.8)\end{array}$ & & $\begin{array}{l}103521 \\
(63.2)\end{array}$ & $\begin{array}{l}104487 \\
(63.8)\end{array}$ & \\
\hline $\begin{array}{l}\text { Insurance type, n } \\
(\%)\end{array}$ & & & 0.023 & & & 0.001 \\
\hline Health insurance & $\begin{array}{l}192102 \\
(91.4)\end{array}$ & $\begin{array}{l}150727 \\
(92.1)\end{array}$ & & $\begin{array}{l}150783 \\
(92.1)\end{array}$ & $\begin{array}{l}150727 \\
(92.1)\end{array}$ & \\
\hline Medical aid & $\begin{array}{l}18026 \\
(8.6)\end{array}$ & $\begin{array}{l}12992 \\
(7.9)\end{array}$ & & $\begin{array}{l}12936 \\
(7.9)\end{array}$ & $\begin{array}{l}12992 \\
(7.9)\end{array}$ & \\
\hline \multicolumn{7}{|c|}{ History of drug use and comorbiditiesin previous year } \\
\hline NSAIDs, n (\%) & & & 0.101 & & & 0.047 \\
\hline No & $\begin{array}{l}54253 \\
(25.8)\end{array}$ & $\begin{array}{l}49710 \\
(30.4)\end{array}$ & & $\begin{array}{l}46189 \\
(28.2)\end{array}$ & $\begin{array}{l}49710 \\
(30.4)\end{array}$ & \\
\hline Yes & $\begin{array}{l}155875 \\
(74.2)\end{array}$ & $\begin{array}{l}114009 \\
(69.6)\end{array}$ & & $\begin{array}{l}117530 \\
(71.8)\end{array}$ & $\begin{array}{l}114009 \\
(69.6)\end{array}$ & \\
\hline Statin drugs, n (\%) & & & 0.068 & & & 0.01 \\
\hline No & $\begin{array}{l}203837 \\
(97.0)\end{array}$ & $\begin{array}{l}160543 \\
(98.1)\end{array}$ & & $\begin{array}{l}160769 \\
(98.2)\end{array}$ & $\begin{array}{l}160546 \\
(98.1)\end{array}$ & \\
\hline Yes & $\begin{array}{l}6291 \\
(3.0)\end{array}$ & $\begin{array}{l}3173 \\
(1.9)\end{array}$ & & $\begin{array}{l}2950 \\
(1.8)\end{array}$ & $\begin{array}{l}3173 \\
(1.9)\end{array}$ & \\
\hline
\end{tabular}




\section{Antiplatelet drugs,}

n (\%)

$\begin{array}{lllll}\text { No } & 208030 & 162635 & 162712 & 162635 \\ & (99.0) & (99.3) & (99.4) & (99.3) \\ \text { Yes } & 2098 & 1084 & 1007 & 1084 \\ & (1.0) & (0.7) & (0.6) & (0.7)\end{array}$

Aspirin, $\mathrm{n}(\%)$

0.053

0.006

No

$206077 \quad 161645$

(98.1)

(98.7)

$161752 \quad 161645$

(98.8)

(98.7)

Yes

$$
414(1.9) \quad 2074
$$

1967

2074

(1.2)

(1.3)

Vitamin K

antagonists, $\mathrm{n}(\%)$

0.024

0.003

No

$209714 \quad 163549$

(99.8)

(100.0)

$163563 \quad 163549$

(99.9)

(99.9)

Yes

$$
414(0.2)
$$

170

$156(0.1)$

170

(0.1)

Factor Xa

inhibitors, n (\%)

No

$209251 \quad 163651$

(99.6)

(100.0)

0.079

$877(0.4) \quad 68(0.0)$

$163648 \quad 163651$

(100.0) (100.0)

Yes

$877(0.4) \quad 68(0.10$

0.002

$71(0.0) \quad 68(0.0)$

Direct thrombin

inhibitors, n (\%)

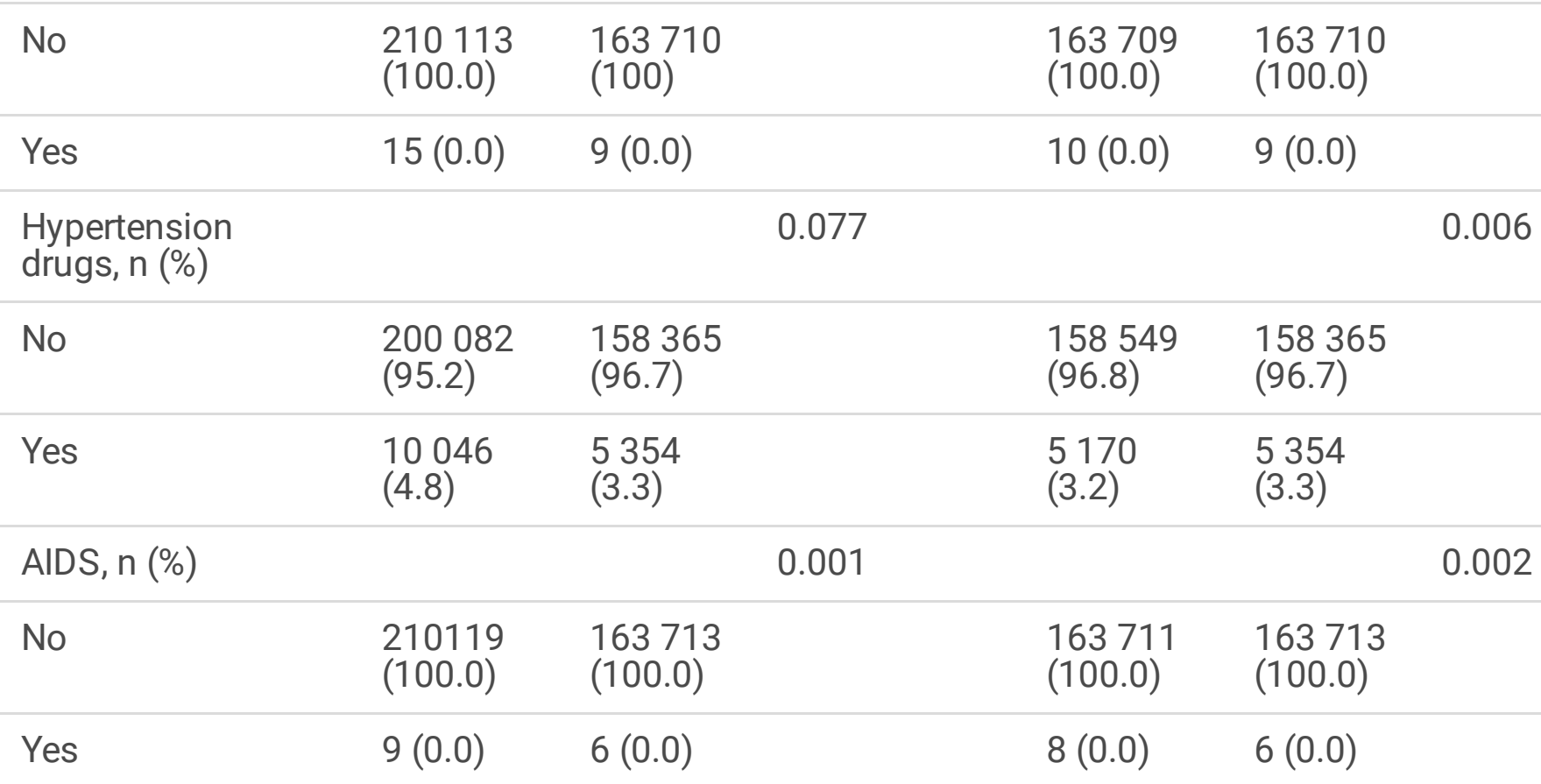




\begin{tabular}{|c|c|c|c|c|c|c|}
\hline $\mathrm{CHF}, \mathrm{n}(\%)$ & & & 0.015 & & & 0.003 \\
\hline No & $\begin{array}{l}201807 \\
(96.0)\end{array}$ & $\begin{array}{l}157694 \\
(96.3)\end{array}$ & & $\begin{array}{l}157776 \\
(96.4)\end{array}$ & $\begin{array}{l}157694 \\
(96.3)\end{array}$ & \\
\hline Yes & $\begin{array}{l}8321 \\
(4.0)\end{array}$ & $\begin{array}{l}6025 \\
(3.7)\end{array}$ & & $\begin{array}{l}5943 \\
(3.6)\end{array}$ & $\begin{array}{l}6025 \\
(3.7)\end{array}$ & \\
\hline CKD, n (\%) & & & 0.048 & & & 0.003 \\
\hline No & $\begin{array}{l}206392 \\
(92.2)\end{array}$ & $\begin{array}{l}161763 \\
(98.8)\end{array}$ & & $\begin{array}{l}161820 \\
(98.8)\end{array}$ & $\begin{array}{l}161763 \\
(98.8)\end{array}$ & \\
\hline Yes & $\begin{array}{l}3736 \\
(1.8)\end{array}$ & $\begin{array}{l}1956 \\
(1.2)\end{array}$ & & $\begin{array}{l}1899 \\
(1.2)\end{array}$ & $\begin{array}{l}1956 \\
(1.2)\end{array}$ & \\
\hline COPD, n (\%) & & & 0.058 & & & 0.012 \\
\hline No & $\begin{array}{l}124299 \\
(59.2)\end{array}$ & $\begin{array}{l}101467 \\
(62.0)\end{array}$ & & $\begin{array}{l}100486 \\
(61.4)\end{array}$ & $\begin{array}{l}101467 \\
(62.0)\end{array}$ & \\
\hline Yes & $\begin{array}{l}85829 \\
(40.9)\end{array}$ & $\begin{array}{l}62252 \\
(38.0)\end{array}$ & & $\begin{array}{l}63233 \\
(38.6)\end{array}$ & $\begin{array}{l}62252 \\
(38.0)\end{array}$ & \\
\hline $\begin{array}{l}\text { Connective tissue } \\
\text { disease, } n(\%)\end{array}$ & & & 0.009 & & & 0.004 \\
\hline No & $\begin{array}{l}188530 \\
(89.7)\end{array}$ & $\begin{array}{l}147356 \\
(90.0)\end{array}$ & & $\begin{array}{l}147158 \\
(89.9)\end{array}$ & $\begin{array}{l}147356 \\
(90.0)\end{array}$ & \\
\hline Yes & $\begin{array}{l}21598 \\
(10.3)\end{array}$ & $\begin{array}{l}16363 \\
(10.0)\end{array}$ & & $\begin{array}{l}16561 \\
(10.1)\end{array}$ & $\begin{array}{l}16363 \\
(10.0)\end{array}$ & \\
\hline CVA or TIA, n (\%) & & & 0.05 & & & 0.002 \\
\hline No & $\begin{array}{l}187245 \\
(89.1)\end{array}$ & $\begin{array}{l}148357 \\
(90.6)\end{array}$ & & $\begin{array}{l}148271 \\
(90.6)\end{array}$ & $\begin{array}{l}148357 \\
(90.6)\end{array}$ & \\
\hline Yes & $\begin{array}{l}22883 \\
(10.9)\end{array}$ & $\begin{array}{l}15362 \\
(9.4)\end{array}$ & & $\begin{array}{l}15448 \\
(9.4)\end{array}$ & $\begin{array}{l}15362 \\
(9.4)\end{array}$ & \\
\hline Dementia, n (\%) & & & 0.05 & & & $<0.001$ \\
\hline No & $\begin{array}{l}204127 \\
(97.1)\end{array}$ & $\begin{array}{l}160313 \\
(97.9)\end{array}$ & & $\begin{array}{l}160310 \\
(97.9)\end{array}$ & $\begin{array}{l}160313 \\
(97.9)\end{array}$ & \\
\hline Yes & $\begin{array}{l}6001 \\
(2.9)\end{array}$ & $\begin{array}{l}3406 \\
(2.1)\end{array}$ & & $\begin{array}{l}3409 \\
(2.1)\end{array}$ & $\begin{array}{l}3406 \\
(2.1)\end{array}$ & \\
\hline Hemiplegia, n (\%) & & & 0.020 & & & 0.004 \\
\hline No & $\begin{array}{l}209716 \\
(99.8)\end{array}$ & $\begin{array}{l}163529 \\
(99.9)\end{array}$ & & $\begin{array}{l}163551 \\
(99.9)\end{array}$ & $\begin{array}{l}163529 \\
(99.9)\end{array}$ & \\
\hline Yes & $412(0.2)$ & $\begin{array}{l}190 \\
(0.1)\end{array}$ & & $168(0.1)$ & $\begin{array}{l}190 \\
(0.1)\end{array}$ & \\
\hline $\begin{array}{l}\text { Myocardial } \\
\text { infarction n (\%) }\end{array}$ & & & 0.028 & & & 0.002 \\
\hline
\end{tabular}




\begin{tabular}{|c|c|c|c|c|c|c|}
\hline No & $\begin{array}{l}207802 \\
(98.9)\end{array}$ & $\begin{array}{l}162361 \\
(99.2)\end{array}$ & & $\begin{array}{l}162390 \\
(99.2)\end{array}$ & $\begin{array}{l}162361 \\
(99.2)\end{array}$ & \\
\hline Yes & $\begin{array}{l}2326 \\
(1.1)\end{array}$ & $\begin{array}{l}1358 \\
(0.8)\end{array}$ & & $\begin{array}{l}1329 \\
(0.8)\end{array}$ & $\begin{array}{l}1358 \\
(0.8)\end{array}$ & \\
\hline $\begin{array}{l}\text { Peptic ulcer } \\
\text { disease, n (\%) }\end{array}$ & & & 0.037 & & & 0.007 \\
\hline No & $\begin{array}{l}133184 \\
(63.4)\end{array}$ & $\begin{array}{l}106698 \\
(65.2)\end{array}$ & & $\begin{array}{l}106168 \\
(64.8)\end{array}$ & $\begin{array}{l}106698 \\
(65.2)\end{array}$ & \\
\hline Yes & $\begin{array}{l}76944 \\
(36.6)\end{array}$ & $\begin{array}{l}57021 \\
(34.8)\end{array}$ & & $\begin{array}{l}57551 \\
(35.2)\end{array}$ & $\begin{array}{l}57021 \\
(34.8)\end{array}$ & \\
\hline $\begin{array}{l}\text { Peripheral } \\
\text { vascular disease, } \mathrm{n} \\
(\%)\end{array}$ & & & 0.020 & & & 0.006 \\
\hline No & $\begin{array}{l}185614 \\
(88.3)\end{array}$ & $\begin{array}{l}145660 \\
(89.0)\end{array}$ & & $\begin{array}{l}145371 \\
(88.8)\end{array}$ & $\begin{array}{l}145660 \\
(89.0)\end{array}$ & \\
\hline Yes & $\begin{array}{l}24514 \\
(11.7)\end{array}$ & $\begin{array}{l}18059 \\
(11.0)\end{array}$ & & $\begin{array}{l}18348 \\
(11.2)\end{array}$ & $\begin{array}{l}18059 \\
(11.0)\end{array}$ & \\
\hline $\begin{array}{l}\text { Liver disease, } \mathrm{n} \\
(\%)\end{array}$ & & & 0.027 & & & 0.004 \\
\hline No & $\begin{array}{l}204069 \\
(97.1)\end{array}$ & $\begin{array}{l}159719 \\
(97.6)\end{array}$ & & $\begin{array}{l}159820 \\
(97.6)\end{array}$ & $\begin{array}{l}159719 \\
(97.6)\end{array}$ & \\
\hline Yes & $\begin{array}{l}6059 \\
(2.9)\end{array}$ & $\begin{array}{l}4000 \\
(2.4)\end{array}$ & & $\begin{array}{l}3899 \\
(2.4)\end{array}$ & $\begin{array}{l}4000 \\
(2.4)\end{array}$ & \\
\hline $\begin{array}{l}\text { Severe liver } \\
\text { disease, n (\%) }\end{array}$ & & & 0.06 & & & 0.001 \\
\hline No & $\begin{array}{l}209610 \\
(99.8)\end{array}$ & $\begin{array}{l}163365 \\
(99.8)\end{array}$ & & $\begin{array}{l}163375 \\
(99.8)\end{array}$ & $\begin{array}{l}163365 \\
(99.8)\end{array}$ & \\
\hline Yes & $518(0.2)$ & $\begin{array}{l}354 \\
(0.2)\end{array}$ & & $344(0.2)$ & $\begin{array}{l}354 \\
(0.2)\end{array}$ & \\
\hline Cancer, n (\%) & & & 0.030 & & & 0.003 \\
\hline No & $\begin{array}{l}199631 \\
(95.0)\end{array}$ & $\begin{array}{l}15670 \\
(95.6)\end{array}$ & & $\begin{array}{l}156681 \\
(95.7)\end{array}$ & $\begin{array}{l}15670 \\
(95.6)\end{array}$ & \\
\hline Yes & $\begin{array}{l}10497 \\
(5.0)\end{array}$ & $\begin{array}{l}7149 \\
(4.4)\end{array}$ & & $\begin{array}{l}7038 \\
(4.3)\end{array}$ & $\begin{array}{l}7149 \\
(4.4)\end{array}$ & \\
\hline $\begin{array}{l}\text { Metastatic cancer, } \\
\text { n (\%) }\end{array}$ & & & 0.009 & & & 0.002 \\
\hline No & $\begin{array}{l}209547 \\
(99.7)\end{array}$ & $\begin{array}{l}163338 \\
(99.8)\end{array}$ & & $\begin{array}{l}163353 \\
(99.8)\end{array}$ & $\begin{array}{l}163338 \\
(99.8)\end{array}$ & \\
\hline Yes & $581(0.3)$ & 381 & & $366(0.2)$ & 381 & \\
\hline
\end{tabular}


Diabetes, n (\%)

No

Yes

Diabetes with

complication, $\mathrm{n}$

(\%)

No

194170

(92.4)

151518

(72.1)

58610

(27.9.)
0.024

119831

(73.2)

43888

(26.8)

0.003

$119604 \quad 119831$

(73.1) (73.2)

$44115 \quad 43888$

(26.9) (26.8)

0.029

0.001

Yes

15958

(7.6).

152531

(93.2)

152470

(93.1)

152531

11188

(6.8)

11249

(6.9)

(93.2)

11188

(6.8)

$\begin{array}{lllllll}\text { Charlsoncomorbity } & 5.25 \pm & 5.12 \pm & 0.001 & 5.13 \pm & 5.12 \pm & 0.001 \\ \text { score, mean } \pm \text { SD } & 1.70 & 1.59 & & 1.59 & 1.59 & \end{array}$

Atrial fibrillation, $\mathrm{n}$

0.027 $<0.001$

(\%)

No $207033 \quad 161818$

(98.5)

(98.8)

161822

(98.8)

161818

Yes

3095

1901

(1.2)

1897

(1.2)

(98.8)

(1.5)

0.002

0.002

Valvular heart

disease, $\mathrm{n}(\%)$

No

$210088 \quad 163692$

(100.0) (100.0)

163687

163692

(100.0)

(100.0)

Yes

$40(0.0) \quad 27(0.0)$

$32(0.0)$

$27(0.0)$

Carotid artery

disease, n (\%)

No

208925

(99.4)

162931

(99.5)

162962

(99.5)

162931

0.013

0.003

Yes

$\begin{array}{ll}1203 & 788 \\ (0.6) & (0.5)\end{array}$

$757(0.5)$

(99.5)

Hypothyroidism, $\mathrm{n}$

(\%)

No

0.003

0.002

788

(0.5)

(96.4)

(96.5)

157988

(96.5)
157928

(96.5) 


$\begin{array}{lllll}\text { Yes } & 7562 & 5791 & 5731 & 5791 \\ & (3.6) & (3.5) & (3.5) & (3.5)\end{array}$

TKA, total knee arthroplasty; PS, propensity score; SD, standard deviation; SiB, simultaneous bilateral; StB, staged bilateral; NSAIDs, non-steroidal anti-inflammatory drugs; AIDS, acquired immune deficiency syndrome; $\mathrm{CHF}$, congestive heart failure; $\mathrm{CKD}$, chronic kidney disease; $C O P D$, chronic obstructive pulmonary disease; CVA, cerebrovascular disease; TIA, transient ischemic attack 
Table 2

Subgroup analyses of risk of stroke with bilateral total knee arthroplasty, compared to unilateral total knee arthroplasty, in PS matched cohort.

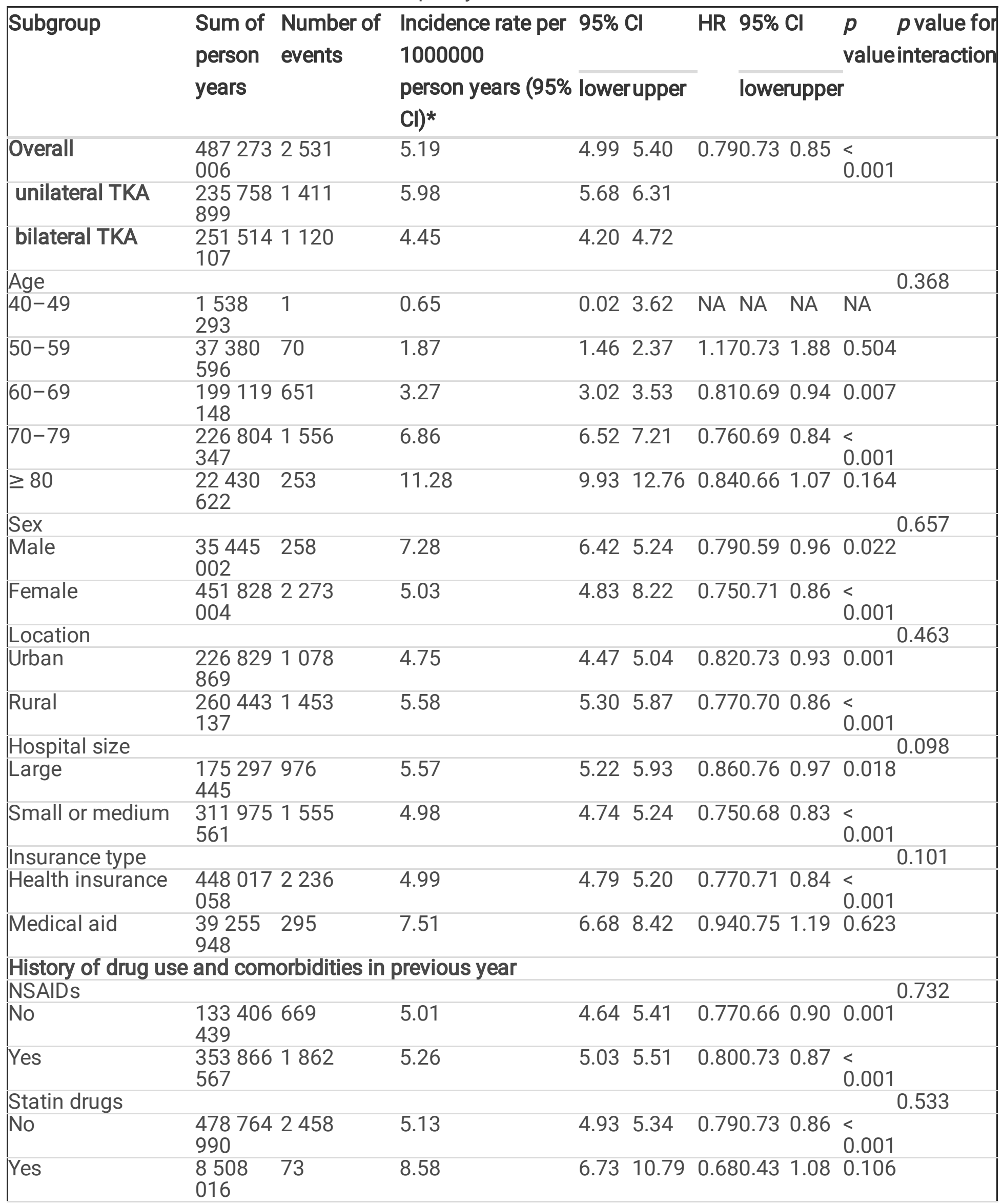




\begin{tabular}{|c|c|c|c|c|c|c|}
\hline Subgroup & $\begin{array}{l}\text { Sum of } \\
\text { person } \\
\text { years }\end{array}$ & $\begin{array}{l}\text { Number of } \\
\text { events }\end{array}$ & $\begin{array}{l}\text { Incidence rate per } \\
1000000 \\
\text { person years }(95 \% \\
\mathrm{Cl}) \star\end{array}$ & lowerupper & $\begin{array}{l}\text { HR } 95 \% \mathrm{Cl} \\
\text { lowerupper }\end{array}$ & $\begin{array}{l}p \quad p \text { value for } \\
\text { value interaction }\end{array}$ \\
\hline Antiplatelet drugs & & & & & & 0.578 \\
\hline No & $\begin{array}{l}484349 \\
186\end{array}$ & 2504 & 5.17 & 4.975 .38 & 0.790 .730 .86 & $\begin{array}{l}< \\
0.001\end{array}$ \\
\hline Yes & $\begin{array}{l}2923 \\
820\end{array}$ & 27 & 9.23 & 6.0913 .44 & 0.630 .291 .37 & 0.246 \\
\hline Aspirin & & & & & & 0.941 \\
\hline No & $\begin{array}{l}481724 \\
149\end{array}$ & 2480 & 5.15 & 4.955 .35 & 0.790 .730 .85 & $\begin{array}{l}< \\
0.001\end{array}$ \\
\hline Yes & $\begin{array}{l}5548 \\
857\end{array}$ & 51 & 9.19 & 6.8412 .08 & 0.770 .451 .34 & 0.361 \\
\hline $\begin{array}{l}\text { Vitamin K } \\
\text { antagonists }\end{array}$ & & & & & & 0.330 \\
\hline No & $\begin{array}{l}486788 \\
236\end{array}$ & 2525 & 5.19 & 4.995 .39 & 0.790 .730 .85 & $\begin{array}{l}< \\
0.001\end{array}$ \\
\hline Yes & 484770 & 6 & 12.38 & 4.5426 .94 & 1.830 .3410 .00 & 00.484 \\
\hline Factor Xa inhibitor & & & & & & 0.973 \\
\hline No & $\begin{array}{l}487137 \\
787\end{array}$ & 2530 & 5.19 & 4.995 .40 & 0.790 .730 .85 & $<.001$ \\
\hline Yes & 135219 & & 7.40 & 0.1941 .20 & NA NA NA & NA \\
\hline $\begin{array}{l}\text { Direct thrombin } \\
\text { inhibitor }\end{array}$ & & & & & & 1.000 \\
\hline No & $\begin{array}{l}487264 \\
451\end{array}$ & 2531 & 5.19 & 4.995 .40 & 0.790 .730 .85 & $\hat{0}_{0.001}$ \\
\hline Yes & 8555 & 0 & 0.00 & 0.00431 .20 & ONA NA NA & \\
\hline Hypertension drugs & & & & & & 0.753 \\
\hline No & $\begin{array}{l}471886 \\
519\end{array}$ & 2383 & 5.05 & 4.855 .26 & $0.790 .73 \quad 0.86$ & 0.082 \\
\hline Yes & $\begin{array}{l}15386 \\
487\end{array}$ & 148 & 9.62 & 8.1311 .30 & 0.750 .541 .04 & $<.001$ \\
\hline AIDS & & & & & & 1.000 \\
\hline No & $\begin{array}{l}487254 \\
281\end{array}$ & 2531 & 5.19 & 4.995 .40 & 0.790 .730 .85 & $<.001$ \\
\hline Yes & 18725 & 0 & 0.00 & 0.00197 .00 & ONA NA NA & NA \\
\hline CHF & & & & & & 0.467 \\
\hline No & $\begin{array}{l}469984 \\
045\end{array}$ & 2378 & 5.06 & 4.865 .27 & 0.790 .730 .86 & $<.001$ \\
\hline Yes & $\begin{array}{l}17288 \\
961\end{array}$ & 153 & 8.85 & 7.5010 .37 & 0.700 .510 .97 & 0.032 \\
\hline CKD & & & & & & 0.622 \\
\hline No & $\begin{array}{l}482451 \\
662\end{array}$ & 2490 & 5.16 & 4.965 .37 & 0.790 .730 .86 & $<.001$ \\
\hline Yes & $\begin{array}{l}4821 \\
344\end{array}$ & 41 & 8.50 & 6.1011 .54 & 0.680 .361 .26 & 0.217 \\
\hline COPD & & & & & & 0.909 \\
\hline No & $\begin{array}{l}302399 \\
164\end{array}$ & 1624 & 5.37 & 5.115 .64 & 0.790 .710 .87 & $\begin{array}{l}< \\
0.001\end{array}$ \\
\hline Yes & $\begin{array}{l}184873 \\
842\end{array}$ & 907 & 4.91 & 4.595 .24 & 0.790 .700 .91 & 0.001 \\
\hline $\begin{array}{l}\text { Connective tissue } \\
\text { disease }\end{array}$ & & & & & & 0.391 \\
\hline No & $\begin{array}{l}435853 \\
149\end{array}$ & 2308 & 5.30 & 5.085 .52 & 0.800 .730 .87 & $<.001$ \\
\hline
\end{tabular}




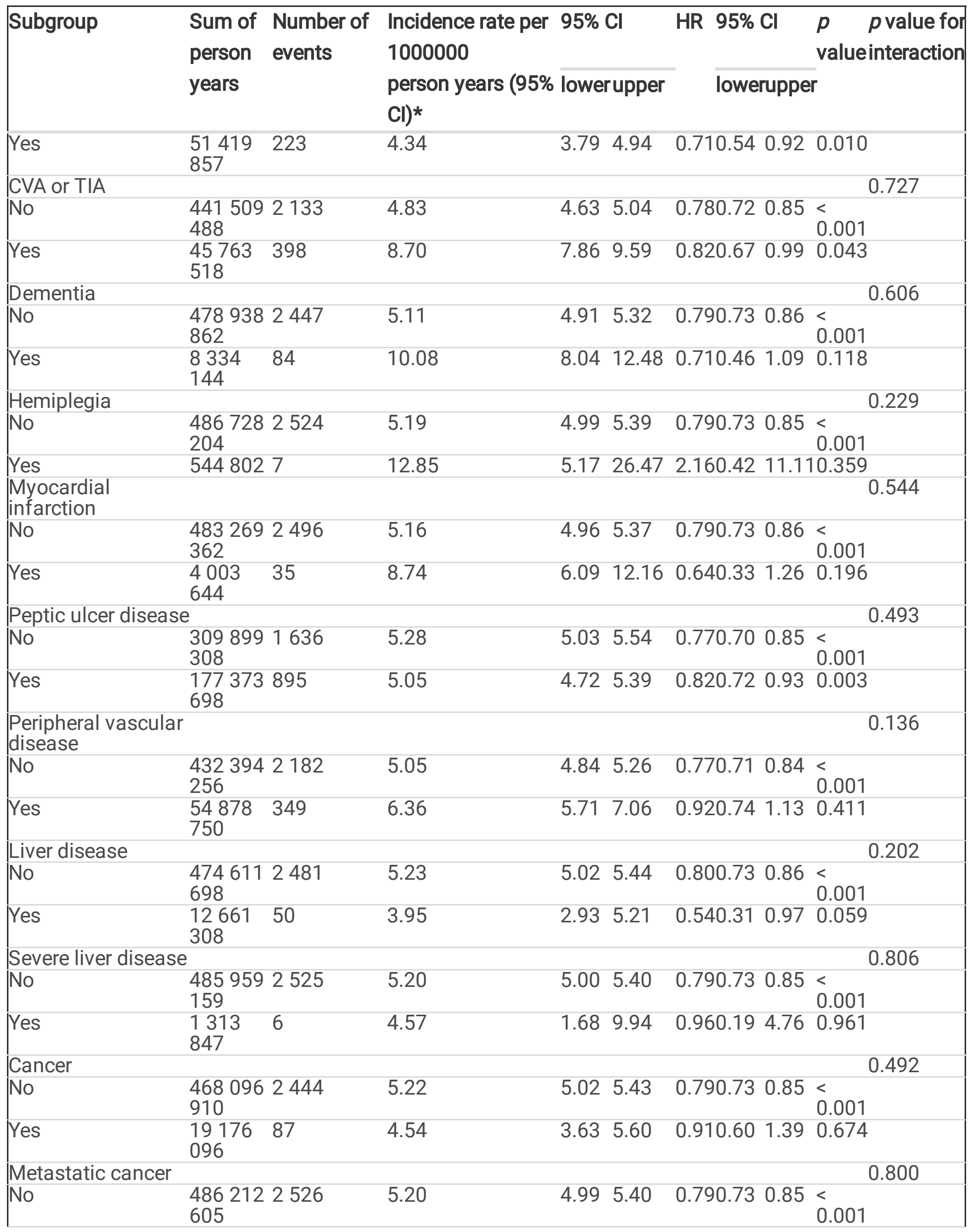




\begin{tabular}{|c|c|c|c|c|c|c|}
\hline Subgroup & $\begin{array}{l}\text { Sum of } \\
\text { person } \\
\text { years }\end{array}$ & $\begin{array}{l}\text { Number of } \\
\text { events }\end{array}$ & $\begin{array}{l}\text { Incidence rate per } \\
1000000 \\
\text { person years }(95 \% \text { I } \\
\text { Cl)* }\end{array}$ & $95 \% \mathrm{Cl}$ & $\begin{array}{l}\text { HR } 95 \% \mathrm{Cl} \\
\quad \text { loweruppe }\end{array}$ & $\begin{array}{l}p \quad p \text { value for } \\
\text { value interaction }\end{array}$ \\
\hline Yes & $\begin{array}{l}1060 \\
401\end{array}$ & 5 & 4.72 & 1.5311 .00 & 0.640 .113 .81 & 0.622 \\
\hline Diabetes & & & & & & 0.684 \\
\hline No & $\begin{array}{l}359206 \\
894\end{array}$ & 1734 & 4.83 & 4.605 .06 & 0.800 .730 .88 & $\begin{array}{l}< \\
0.001\end{array}$ \\
\hline Yes & $\begin{array}{l}128066 \\
112\end{array}$ & 797 & 6.22 & 5.806 .67 & 0.770 .670 .89 & $\begin{array}{l}< \\
0.001\end{array}$ \\
\hline $\begin{array}{l}\text { Diabetes with } \\
\text { complication }\end{array}$ & & & & & & 0.757 \\
\hline No & $\begin{array}{l}454116 \\
703\end{array}$ & 2288 & 5.04 & 4.835 .25 & 0.790 .730 .86 & $<.001$ \\
\hline Yes & $\begin{array}{l}33156 \\
303\end{array}$ & 243 & 7.33 & 6.448 .31 & 0.760 .590 .98 & 0.034 \\
\hline Atrial fibrillation & & & & & & 0.936 \\
\hline No & $\begin{array}{l}483244 \\
151\end{array}$ & 2453 & 5.08 & 4.885 .28 & 0.790 .730 .85 & $\begin{array}{l}< \\
0.001\end{array}$ \\
\hline Yes & $\begin{array}{l}4028 \\
855\end{array}$ & 78 & 19.36 & 15.3024 .16 & 0.800 .511 .26 & 0.337 \\
\hline $\begin{array}{l}\text { Valvular heart } \\
\text { disease }\end{array}$ & & & & & & 0.973 \\
\hline No & $\begin{array}{l}487184 \\
407\end{array}$ & 2530 & 5.19 & 4.995 .40 & 0.790 .730 .85 & $\begin{array}{l}< \\
0.001\end{array}$ \\
\hline Yes & 88599 & 1 & 11.29 & $0.29 \quad 62.89$ & NA NA NA & NA \\
\hline $\begin{array}{l}\text { Carotid artery } \\
\text { disease }\end{array}$ & & & & & & 0.385 \\
\hline No & $\begin{array}{l}485545 \\
773\end{array}$ & 2509 & 5.17 & $4.97 \quad 5.37$ & 0.790 .730 .85 & $<.001$ \\
\hline Yes & $\begin{array}{l}1727 \\
233\end{array}$ & 22 & 12.74 & $7.98 \quad 19.28$ & 1.150 .502 .66 & 0.749 \\
\hline Hypothyroidismm & & & & & & 0.786 \\
\hline No & $\begin{array}{l}471135 \\
808\end{array}$ & 2466 & 5.23 & 5.035 .44 & 0.790 .730 .85 & $<.001$ \\
\hline Yes & $\begin{array}{l}16137 \\
198\end{array}$ & 65 & 4.03 & 3.115 .13 & 0.840 .521 .38 & 0.497 \\
\hline \multicolumn{7}{|c|}{$\begin{array}{l}\text { TKA, total knee arthroplasty; PS, propensity score; HR, hazard ratio; Cl, confidence interval; NSAIDs, non- } \\
\text { steroidal anti-inflammatory drugs; AIDS, acquired immune deficiency syndrome; CHF, congestive heart } \\
\text { failure; CKD, chronic kidney disease; COPD, chronic obstructive pulmonary disease; CVA, cerebrovascular } \\
\text { disease; TIA, transient ischemic attack } \\
\text { *lncidecnce rate=(No of events/sum of person years)x } 1000000 ; 95 \% \text { Cl calculated assuming Poisson } \\
\text { distribution. }\end{array}$} \\
\hline
\end{tabular}


Table 3

Association between unilateral TKA and bilateral TKA

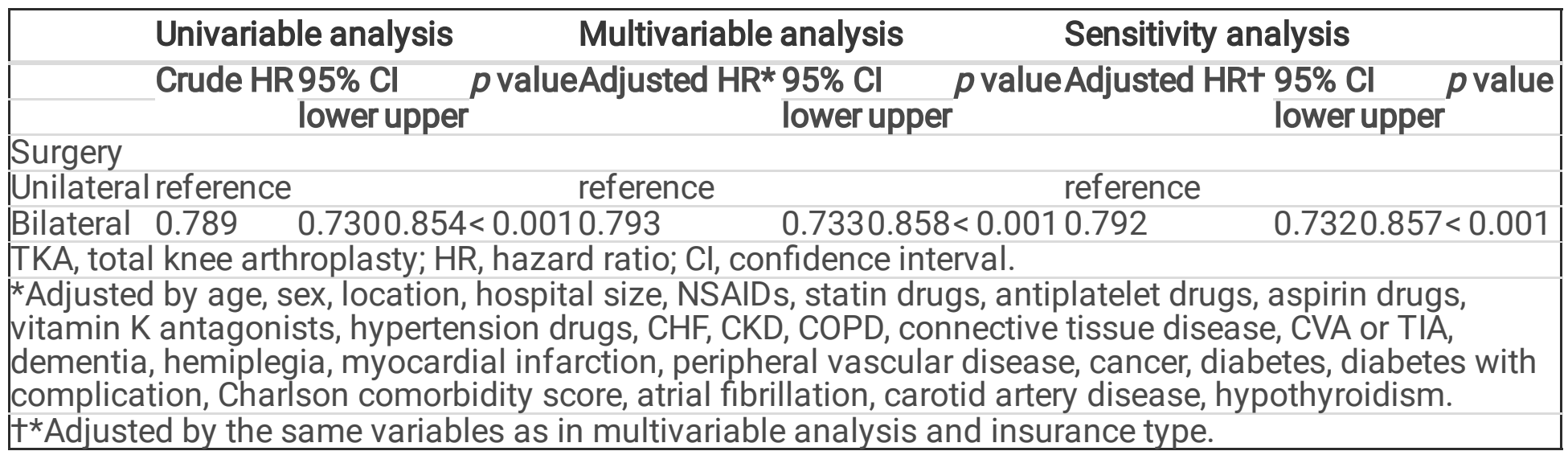

\section{Figures}

\section{National Health Insurance Claims Database}

Patients who treated with primary total knee arthroplasty (TKA) between January 12009 and August 312017 (Patients= 396 703)

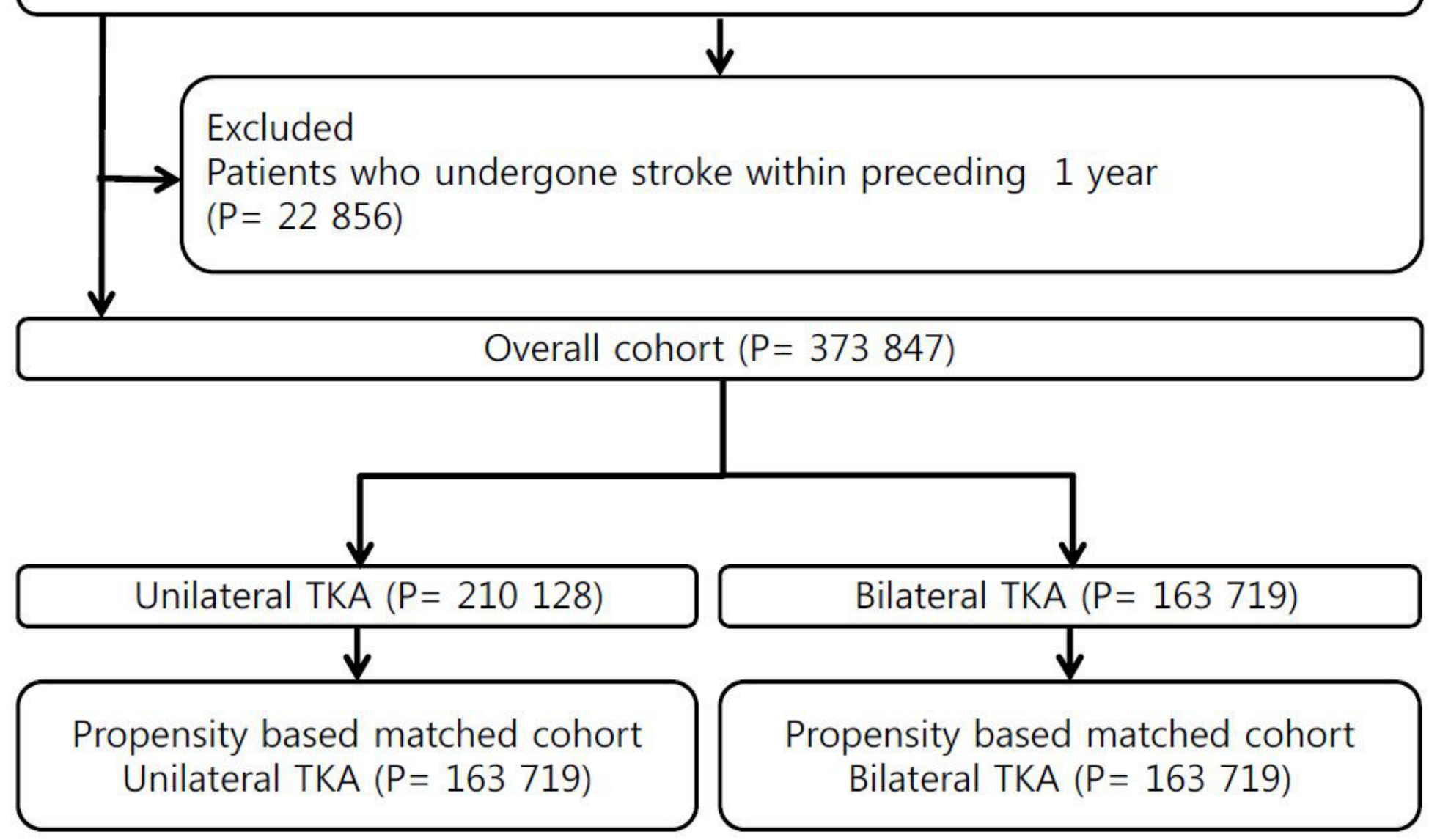

Figure 1 
Selection of study participants from National Health Insurance Claims Database in restrospective cohort design.

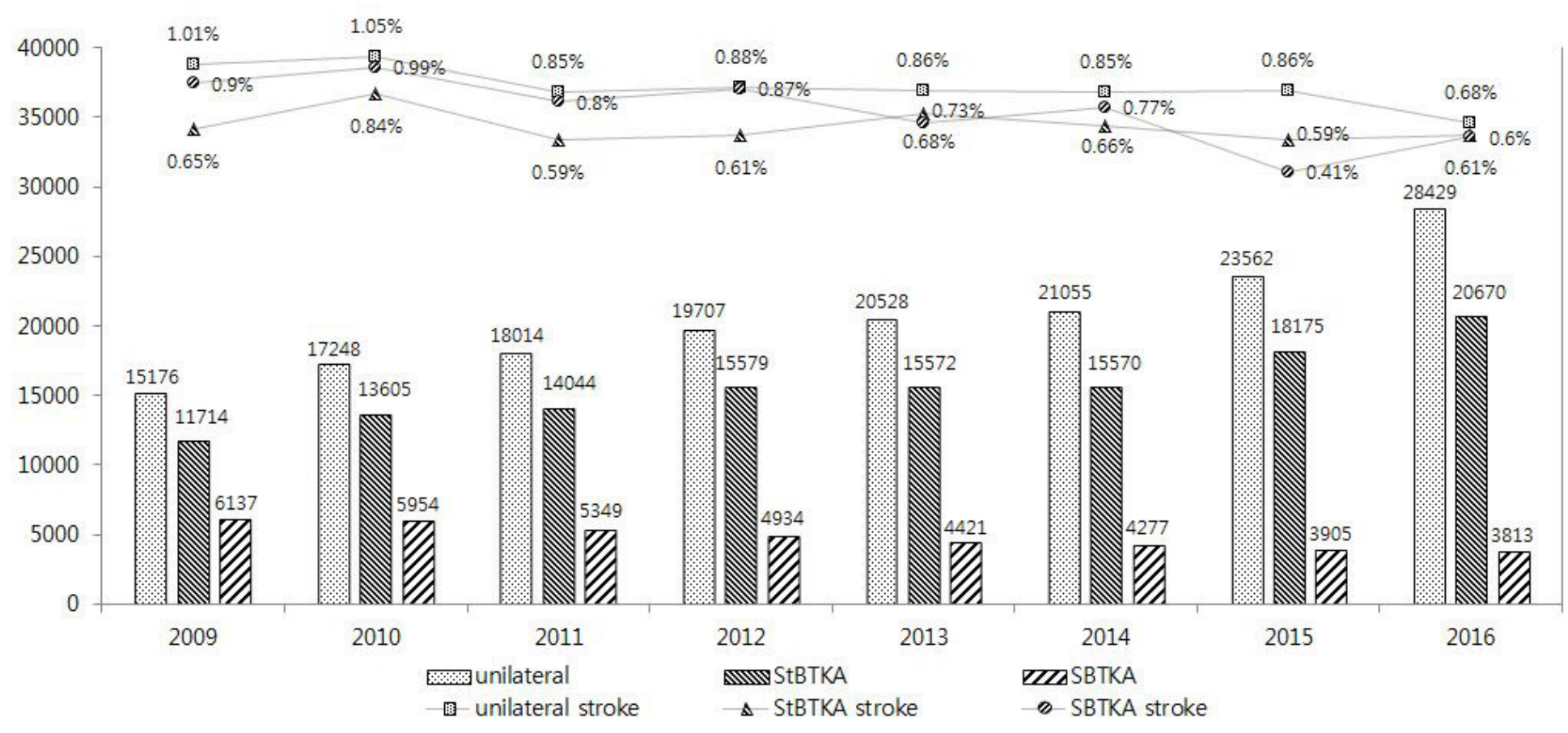

Figure 2

The association of incidence of stroke and annual procedure volume after unilateral TKA or bilateral TKA in South Korea during the study period. 


\section{Covariate balance assessment}

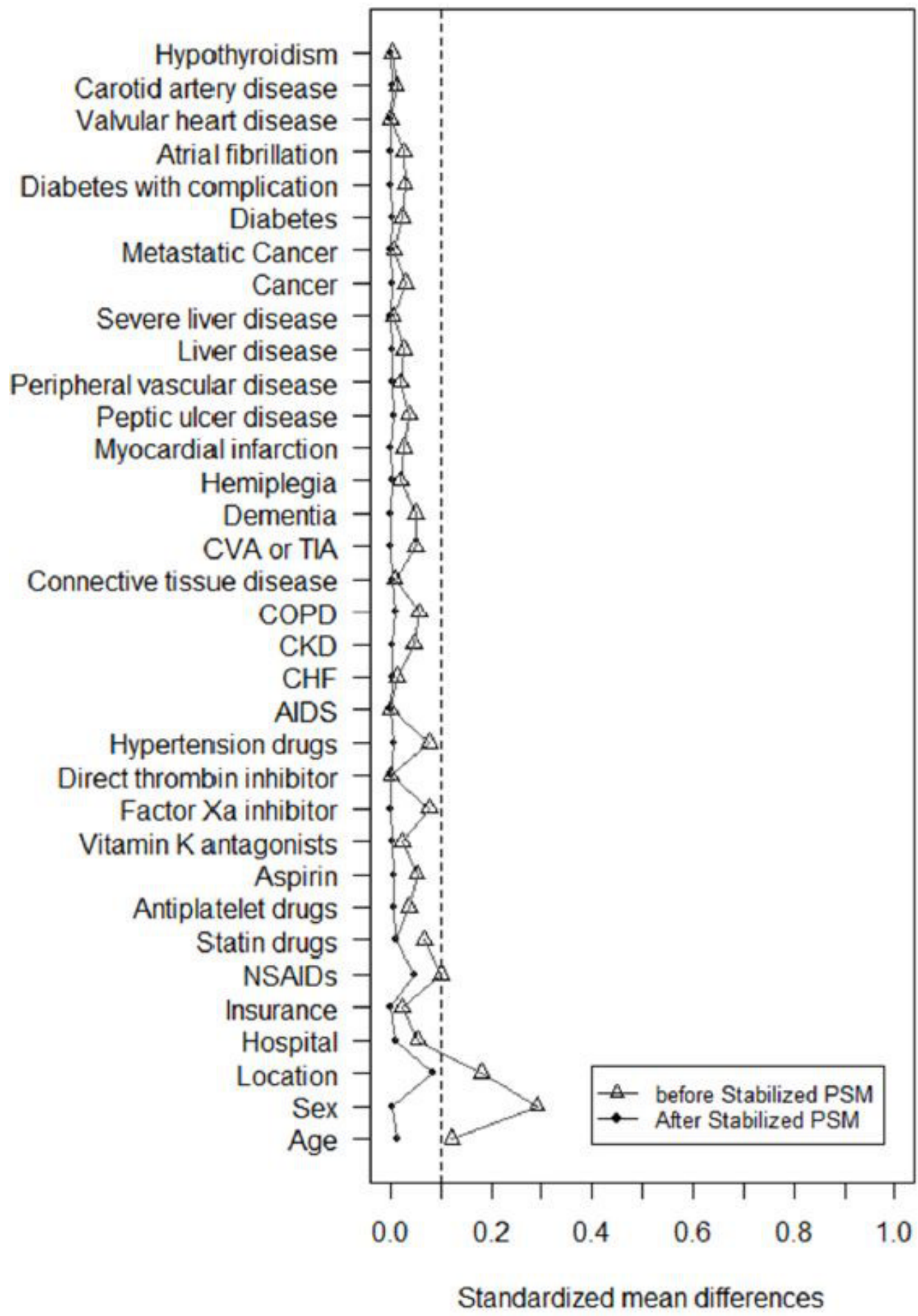

Figure 3

Standardized differences in key baseline characteristics for the unmatched dataset and the dataset weighted by the stabilized propensity score matching (PSM).

\section{Supplementary Files}


This is a list of supplementary files associated with this preprint. Click to download.

- IRBdocument.pdf 